\title{
Coronary Anomaly
}

National Cancer Institute

\section{Source}

National Cancer Institute. Coronary Anomaly. NCI Thesaurus. Code C101314.

Any deviation from normal in the coronary vasculature. 